\title{
PLANT COMMUNITIES OF TRAVERTINE OUTCROPS OF THE SATURNIA AREA IN SOUTHERN TUSCANY (CENTRAL ITALY)
}

\author{
Daniele VICIANI ${ }^{1}$, Barbara MAFFEI ${ }^{1} \&$ Federico SELVI ${ }^{2}$
}

\begin{abstract}
A phytosociological survey was carried out in a poorly known travertine area of southern Tuscany harbouring a rich vegetation mosaic with chamaephytic garrigues, species-rich xerophytic grasslands, chasmophytic coenoses, annual species-dominated communities, shrublands and thermophilous deciduous forests. Field sampling and data analysis allowed to identify and characterize several community types, some of which of significant interest due to their ecological specificity and rarity in peninsular Italy. In particular, our data confirm the associations Pistacio terebinthi-Paliuretum spinosae and Pistacio terebinthi-Quercetum pubescentis, respectively a shrub and forest community type previously unknown for Tuscany. In addition, a new therophytic association of travertine debris named Sedetum hispanico-caespitosi and placed in the Hypochoerion achyrophori alliance (Brachypodietalia distachyi order, Tuberarietea class) is also described. Finally, dynamic relationships between the vegetation types are highlighted and the presence of conservation priority habitats in the area are pointed out.

Key words: phytosociology, vegetation, travertine outcrops, shrublands, annual Sedum-rich communities, Sedetum hispanico-caespitosi.

\section{Izvleček}

Opravili smo fitocenološko raziskavo na malo znanem območju na travertinu v južni Toskani z bogatim mozaikom vegetacije $\mathrm{z}$ hamefitskimi garigami, vrstno bogatimi kserofitskimi travniki, hazmofitskimi združbami, združbami prevladujočih enoletnic, grmišči in termofilnimi listantimi gozdovi. S terenskim vzorčenjem in analizo podatkov smo opisali in označili številne vegetacijske tipe. Nekateri so še posebej pomembni, ker so ekološko posebni in redki na italijanskem poltotoku. Potrdili smo prisotnost asociacij Pistacio terebinthi-Paliuretum spinosae in Pistacio terebinthi-Quercetum pubescentis, grmiščnih in gozdnih združb, ki sta bili do sedaj neznani v Toskani. Opisali smo novo terofitsko asociacijo na travertinskem grušču Sedetum hispanico-caespitosi in jo uvrstili v zvezo Hypochoerion achyrophori (red Brachypodietalia distachyi, razred Tuberarietea). Prikazali smo dinamične odnose med vegetacijskimi tipi in izpostavili naravovarstveno prednostne habitate na raziskovanem območju. Ključne besede: fitosociologija, vegetacija, travertin, grmišča, enoletne združbe z vrstami rodu Sedum, Sedetum hispanico-caespitosi.
\end{abstract}

\section{INTRODUCTION}

Although the ecological and landscape value of southern Tuscany is today widely recognized, plant diversity of this large territory is still incompletely unknown at both the species and community level. One of the interesting sites still waiting for a vegetation study is the travertine area of Poggio Bagno Santo and Pian di Palma (Manciano) in the middle part of the Albegna river valley, in the internal part of the historical region of Maremma (Grosseto province). This site is partially included in the Natura 2000 network, SCI "Medio corso del Fiume Albegna" (Regione Toscana 2010) and is recognized as one of the important biotopes of the Grosseto territory for its

\footnotetext{
${ }^{1}$ Laboratory of plant Biology, Department of Biology, University of Florence, via G. La Pira 4, I-50121 Florence, Italy; email: daniele.viciani@unifi.it

${ }^{2}$ Department of Agricultural, Food and Environmental Sciences, Section of Plant and Soil Science, University of Florence, p. le delle Cascine 28, I-50144 Florence, Italy; email: selvi@unifi.it
} 
floristic richness and peculiar vegetation (Selvi \& Stefanini 2005). Such a diversity is largely due to the occurrence of a mosaic including shrublands in the upper parts of the hill, alternated with sparse chasmophytic and lithophytic herb communities on the rocky travertine outcrops and cliffs, and relatively mature forest communities on the lower part of the slopes. Low garrigues and species-rich herbaceous communities, alternatively dominated by hemicryptophytes and chamaephytes or therophytes in the more xeric conditions, colonize the openings of the shrub-
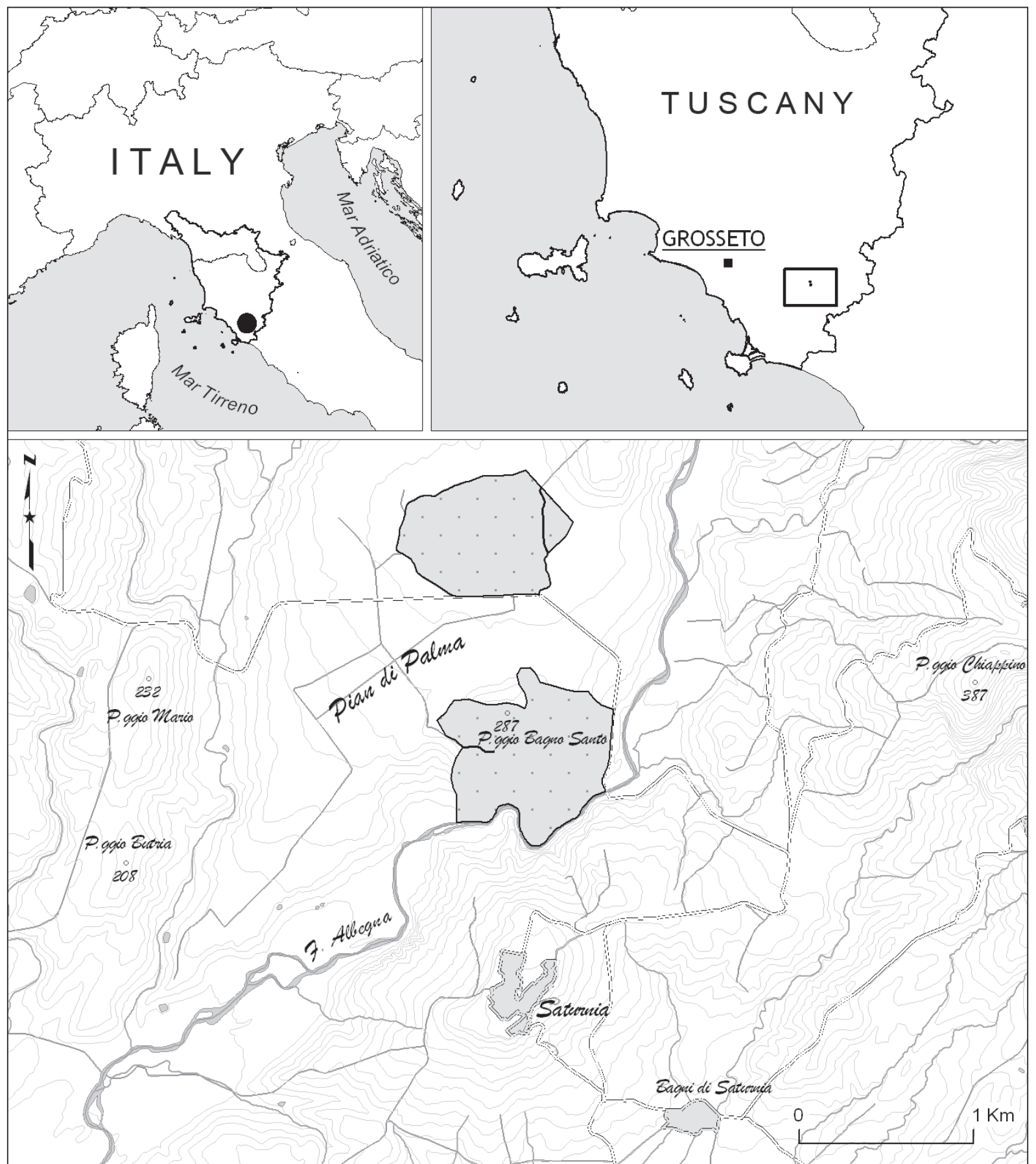

Figure 1: Geographic location of the studied sites, with magnification of the areas of Poggio Bagno Santo and Pian di Palma. Figure 1: Geografski položaj proučevanih rastišč s povečanim ombočjem Poggio Bagno Santo in Pian di Palma. 
lands and the flat areas of Pian di Palma. Along with natural variation of site conditions, grazing by sheep is a major determinant of this mosaic, as typical in many Mediterranean ecosystems.

Since available vegetation data were still largely incomplete, however, additional fieldwork was carried out to better characterize and classify the communities of this area by means of the phytosociological approach. This work allowed to confirm the presence of forest, shrub and herbaceous communities with a distinct easternMediterranean character, some of which were not previously known from Tuscany. Results are described in this paper to provide a contribution to the botanical knowledge of this region and, possibly, a tool for the management of the more valuable habitats in the biotope.

\section{METHODS}

\subsection{Study Area}

\subsubsection{Geographical location and geomorpho- logical aspects}

Poggio Bagno Santo is a low travertine hill (286 $\mathrm{m}$ a.s.l.) located at the northwest of Saturnia in southern Maremma, on the right bank of the Albegna river. The northern slopes are gently connected to the flat travertine pavement of Pian di Palma, while the southern slope is characterized by high and rugged cliffs dominating the Albegna river (Figure 1). In this part the river flows with a marked slope in a narrow gorge between Poggio Bagno Santo and Poggio Pancotta $(268 \mathrm{~m})$ and Poggio Saturnia $(294 \mathrm{~m})$ on the left bank.

The whole area is composed by recent travertine deposits, mainly originated during the Pleistocene period (Servizio Geologico d'Italia 1965). Travertine is a very porous and permeable sedimentary rock with a chemical and organogenic origin, consisting of calcium carbonate crystals (Press \& Siever 1985, Uggeri 2003). Travertine quarries are still active in the area of Pian di Palma, while those on Bagno Santo were abandoned several decades ago.

The area is also known since ancient times for its geothermal activity. Hot water springs are located at the foot of the hills, as the one occurring on the southwestern slope of Bagno Santo after which the hill takes its name.

\subsubsection{Climate}

Thermopluviometric data can be inferred from the Manciano bioclimatic station, which is located at a higher altitude (443 m a.s.l.) and shows a slightly lower mean annual temperature $\left(13.4^{\circ} \mathrm{C}\right)$ and slightly higher mean annual rainfall $(867 \mathrm{~mm})$. According to the climate classification by Thornthwaite \& Mather (1957), the climate formula of Manciano is B'2 b'4 C2 (Bigi \& Rustici (1984), while in the Rivas-Martinez \& Rivas-Saenz (1996-2009) bioclimatic system this site falls in the category "Mediterranean pluviseasonal-oceanic" (Figure 2). Summer drought is therefore relatively pronounced especially in the Bagno Santo area, due to the lower altitude with respect of Manciano and especially the shallow rocky substrate consisting of a very porous rock such as the travertine.

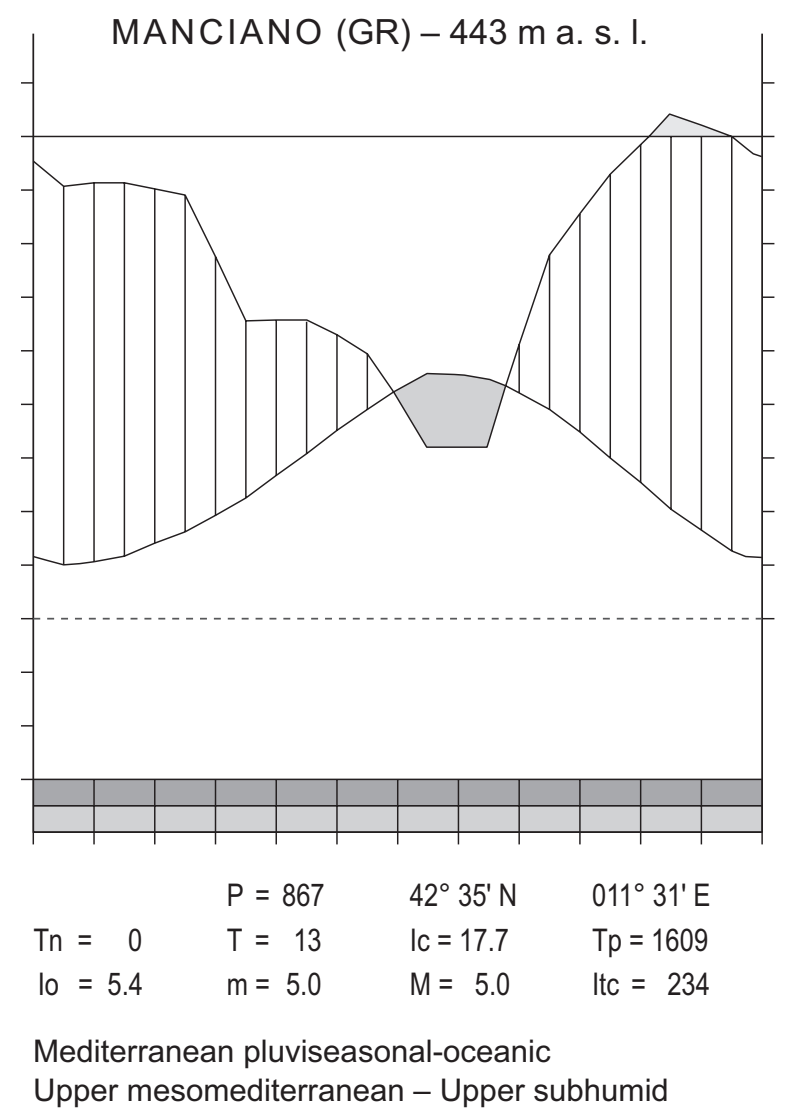

Figure 2: Bioclimatic diagram and diagnosis of the Manciano thermopluviometric station, according to Rivas-Martinez \& Rivas-Saenz (1996-2009).

Slika 2: Bioklimatski diagram in analiza podatkov termopluviometrične postaje Manciano v skladu z Rivas-Martinez \& Rivas-Saenz (1996-2009). 


\subsection{DATA GOLlEGTION AND ANALYSiS}

This study is based on the classical Zurich-Montpellier approach (Braun-Blanquet, 1932; 1964), including his recent developments (Westhoff \& Van Der Maarel, 1973; Géhu \& Rivas-Martínez, 1981; Biondi, 2011; Blasi et al., 2011; Pott, 2011). After a preliminary study of the local flora in the years 2005-2008, we carried out 24 phytosociological relevés between late April and early May of the years 2008-2010, in order to sample the most representative community types.

Field data were first grouped in a raw table that was explored using cluster analysis as implemented in PAST software (Hammer et al. 2001). Abundance-dominance values were transformed according to Van Der Maarel (1979) and Noest et al. (1989), before calculating the Euclidean Distance matrix between the relevés and submit it to hierarchical clustering using the UPGMA algorithm. Plant names follow basically Tutin et al. (1964-80, 1993) and Pignatti (1982), with some later modifications as reported in the Checklist of the Italian Vascular Flora (Conti et al. 2005, 2007) and the recent checklist of the flora of Tuscan Maremma (Selvi 2010). Syntaxonomical nomenclature above the association level is in line with the Phytosociological Nomenclature Code (Weber et al. 2000) and largely based on RivasMartínez et al. (2002).

\section{RESULTS AND DISCUSSION}

Cluster analysis resulted in the dendrogram shown in Figure 3. Five physiognomically consistent groups could be recognized: herb communi-

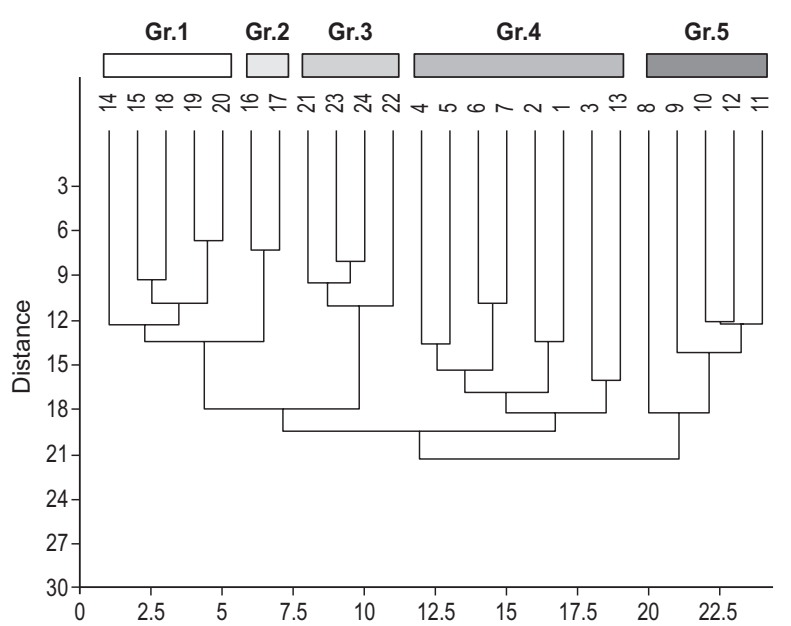

ties of flat travertine pavements (group 1), small herb communities of cliffs and rocks (group 2), garrigues and grasslands (group 3), open woods and shrublands (group 4) and forests (group 5). Each of these groups is described below.

\subsection{ANNUAL-DOMINATED GOMMUNITIES OF FLAT TRAVERTINE PAVEMENTS}

The relevés of group no. 1 in the dendrogram are shown in Table 1 . They describe sparse communities dominated by small Mediterranean annuals colonizing the flat surfaces of travertine debris, with a thin layer of organic soil and abundant mosses. Dominating species are the succulent Sedum caespitosum and Sedum hispanicum, along with Plantago lagopus, Saxifraga tridactylites, Arenaria leptoclados, Cerastium brachypetalum s.l., Minuartia hybrida, Trifolium tomentosum, Trifolium nigrescens and the grasses Poa bulbosa, Catapodium rigidum and Vulpia ciliata.

Selvi \& Stefanini (2005) provisionally referred these communities to the Alysso-Sedion albi, that correspond to the EU prioritary habitat "Rupicolous calcareous or basophilic grasslands of the Alysso-Sedion albi" (Natura 2000 code: 6110; European Commission, 2007). According to the authors who described this alliance (Oberdorfer 1978), however, the vegetation of this syntaxon is characterized by abundant Sedum album and/or perennial species of Sedum, with also other annual species. Several authors have reported vegetation types of the Alysso-Sedion albi from central Italy, such as Venanzoni \& Gigante (1999) from Umbria, Scoppola \& Angiolini (2001) and Angiolini et al. (2009) from southern Tuscany, Di Pietro et al. (2006) from the Prenestini mountains around Rome, Foggi \& Venturi (2009) from the Prato province in northern Tuscany, and Lastrucci et al. (2009) from eastern Tuscany. These authors describe associations or groupings usually dominated by perennial species of Sedum. Recently Fanelli (2007) described the association Chaenorhino rubrifolii-Saxifragetum tridactylites from the travertine area of Bagni di Tivoli near Rome and classified it in the Alysso-Sedion albi al-

Figure 3: Dendrogram from UPGMA cluster analysis of the vegetation relevés.

Slika 3: Dendrogram UPGMA klasterske analize vegetacijskih popisov. 
liance in spite of the large prevalence of therophytes. Even more recently, Fanelli et al. (2010) recognized that several European authors exclude the annual-dominated communities from the alliance Alysso-Sedion albi (e.g. De Foucault 1999, Rivas-Martinez et al. 1997, 2002), though finally following the same classification of the Chaenorhino rubrifolii-Saxifragetum tridactylites association.

Due to the dominance of annual species and the nearly complete lack of perennial species of Sedum in our relevés, we therefore refer the examined communities to the class of the terophytic Mediterranean meadows. This class has been subject to contrasting nomenclatural interpretations (Braun-Blanquet et al. 1952; De Foucault 1999; Brullo et al. 2001; Fanelli et al. 2010) and indicated as Thero-Brachypodietea, Tuberarietea/ Helianthemetea, Stipo-Trachynietea and other names. According to the classification followed here (Rivas-Martinez et al. 2002), this syntaxon is called Tuberarietea.

Phytosociological works on carbonatic substrates in the temperate-oceanic areas of Latium refer similar annual-dominated vegetation types to the associations Trifolio scabri-Hypochoeridetum achyrophori and Saxifrago-Hypochoeridetum achyrophori (Scoppola et al. 2001). These associations include several species also found in our relevés but differ substantially in the dominant species, and cannot be used to classify the Bagno Santo community.

In a recent paper, Fanelli et al. (2010) discussed the syntaxonomy of the basophilous nanophanerophytic vegetation in central Italy based on above 100 phytosociological relevés, both published or unpublished. They suggest that this vegetation type, usually included in the single association Trifolio scabri-Hypochoeridetum achyrophori, is characterized by wide floristic variations and should be split in at least five distinct associations (Medicagini rigidulae-Trifolietum scabri, Trifolio scabri-Hypochoeridetum achyrophori, Hippocrepido siliquosae-Brachypodietum distachyi, Trigonello gladiatae-Brachypodietum distachyi, Crucianello latifoliae-Hypochoeridetum achyrophori). In their large general table, however, only three relevés include Sedum caespitosum and S. hispanicum. These relevés, which are anyway dominated by other species, represent the meadow vegetation on limestone (not travertine) areas of M. Castagneto-La Spera near Rieti and had already been discussed by Scoppola \& Angiolini (2001).
None of the nanophanerophytic associations described to date is therefore physiognomically dominated by Sedum caespitosum and characterized by $S$. hispanicum. The former is a stenomediterranean species with a discontinuos distribution in Central and Southern Italy (Pignatti, 1982), whereas the latter is a more widely distributed Southeastern European taxon relatively unfrequent in Tuscany. Accordingly, these community can be referred to the new association Sedetum hispanico-caespitosi ass. nova hoc loco (typus rel. 20, Table 1). Besides the two Sedum species, constant differential species of this association are Plantago lagopus and Saxifraga tridactylites, as well as several others of higher syntaxonomical rank such as Arenaria leptoclados, Catapodium rigidum, etc. or typical of annual Mediterranean meadows (Anthemis arvensis, Poa bulbosa, etc.).

Concerning the higher ranks, Biondi \& Guerra (2008) recently analyzed the syntaxonomy of the Italian annual meadows and described the endemic alliance Hypochoerion achyrophori. Following this classification, the new association can be placed in the northern and central Italian suballiance Hypochoerenion achyrophori. Alternative placements would have been in the Sedenion caespitosi suballiance according to Rivas-Martinez et al. (2002), or in the Trachynion distachyae alliance according to Fanelli et al.(2010).

\subsection{Chasmophytic and GOMOphytic VEGETATION OF STEEP ROCKS AND CLIFF EDGES}

Another small group consists of two relevés (Table 2) representing the community type colonizing the steep and rugged travertine rocks $\left(10-30^{\circ}\right.$ inclination) and the edge of cliffs over the Albegna river on Poggio Bagno Santo. This community includes either chasmophytic or comophytic species (plants growing in small soil pockets found in rock fissures), often developed in partial shade by forest and shrub vegetation surrounding such rocky surfaces. Dominant species are the hemicryptophyte Cymbalaria muralis (casmophytic) and the geophytes Umbilicus rupestris, Muscari commutatum and Allium subhirsutum (comophytic). Though not recorded in the relevés presented here, Anthirrhinum latifolium and Sedum rupestre are often found in these phytocoenoses, as well as the xerophytic ferns Polypodium cambricum and Asplenium trichomanes. Other species appear in 
the fissures of the partially shaded rocks containing pockets of nutrient-rich soil from the mineralization of forest litterfall, such as the therophytes Geranium purpureum, a species of dry forest edges, Galium aparine, Centranthus calcitrapa, Arabis turrita and Parietaria officinalis.

From the floristic point of view it is especially worth of note the presence of a conspicuous population of Muscari commutatum (Liliaceae) in the narrow fissures of travertine rocks of Bagno Santo, due the rarity of this bulbous geophyte in Italy. As a rare Mediterranean taxon it is included in the national list of the threatened plants and as a relevant species for the recognition of the IPAs in the country (Blasi et al. 2010).

Concerning the syntaxonomical classification of this type of vegetation we refer to Brullo \& Guarino (2002), who published a synthetic treatment of the chasmophytic synantropic vegetation in Italy. Unlike in previous works (cited in Brullo \& Guarino 1999), these authors place the phytocoenoses of natural cliffs and rock ledges and those of walls in two distinct classes, respectively Asplenietea trichomanis and Parietarietea judaicae. Among the characteristic species of the latter class, our samples include Cymbalaria muralis and Umbilicus rupestris, along with several other rupiculous plants. The presence of the somewhat nitrophilous species Parietaria officinalis, instead of $P$. judaica, indicates the presence of local deposits of nutrient-rich soil connected to forest edges.

Accordingly we provisionally refer the relevés of Table 2 to an informal grouping with Cymbalaria muralis, Muscari commutatum and Allium subhirsutum within the Parietarietea class.

\subsection{Chamaephytic Garkigues With EUPHORBIA SPINOSA AND SATUREJA MONTANA}

The travertine plateau of Pian di Palma is characterized by a low garrigue community dominated by the two Mediterranean chamaephytes Euphorbia spinosa and Satureja montana (Table 3). Soil cover resulted relatively high also due to the abundance of other shrublets such as Teucrium capitatum and Helichrysum italicum and robust herbs and grasses such as Cephalaria leucantha, Bromus erectus, Convolvulus cantabrica and Thymus longicaulis. On the whole, these species indicate shallow carbonatic lithosoils with little organic material, under very slow pedogenetic evolution.

Satureja montana is a widespread Mediterranean species of mountain areas. Along the whole Apennine chain it is often dominant in the garrigues developed on various carbonatic substrates, even at relatively high altitudes. Euphorbia spinosa is also a basophilous species often abundant in limestone and serpentine garrigues, but more thermophilous and usually at lower altitudes than S. montana (Pignatti 1982, Allegrezza et al. 1997). According to Allegrezza et al. (1997), the rocky habitats of the limestone hills in central Italy harbour distinct associations with Satureja montana, some of which show floristic and ecological similarity with the Pian di Palma travertine community. In particular, the more thermophilous aspect of the Cephalario leucanthae-Saturejetum montanae, described as subass. euphorbietosum spinosae, is the community type that better corresponds to our vegetation samples for the cenological conditions and the presence of several characteristic species. The same association was also reported from some travertine areas between Siena and Viterbo (Scoppola \& Angiolini 1997), but in a distinct variant characterized by the endemic Santolina etrusca that is lacking at Pian di Palma because of the carbonatic lithosoil.

According to Scoppola \& Angiolini (1997), the Cephalario leucanthae-Saturejetum montanae association belongs to the alliance Artemisio albae-Saturejion montanae of the Mediterranean Rosmarinetea class, although the number of Mediterranean species decreases going towards the more inland areas and the communities become progressively more atypical for the class.

\subsection{MESOXEROPHILOUS BROMUS ERECTUS GRASSLANDS}

A second community type (Table 4) found on the travertine plateau of Pian di Palma occurs on slightly more evolved soils with a higher content of organic matter. Here, soil cover by xerophytic perennial herbs and grasses reaches $70-80 \%$, while chamaephytes are less abundant than in the Cephalario-Saturejetum. Most typical species of this community are Bromus erectus and other hemicryptophytes such as Koeleria splendens, Eryngium campestre, Convolvulus cantabrica, Cephalaria leucantha, Urospermum dalechampii, Galium corrudifolium, Potentilla hirta, Tragopogon dubius, 
Carlina corymbosa, Anthyllis vulneraria subsp. rubriflora, etc. The mainly W Mediterranean geophytes Allium moschatum and Iris lutescens are also relatively common, as well as the orchids Orchis morio, Serapias vomeracea and others observed outside the vegetation relevés. Annual species were not numerous, among them Helianthemum salicifolium and Tordylium apulum.

The phytosociological classification of the perennial grasslands of the Brometalia erecti order in the Apennines has been revised by Biondi et al. (1995, 2005), though recent studies suggest to place these communities in a separate syntaxon at the order level due to their floristic and ecological distinctness (Di Pietro 2011, Di Pietro et al. 2012). According to the recent study by Biondi \& Galdenzi (2012), the order Brometalia erecti is restricted to north-western Italy (up to western Tuscany), while most Apennine communities belong to the Scozonero villosae-Chrysopogonetalia grylli.

Our vegetation samples include characteristic and differential species of the order Brometalia erecti, such as Bromus erectus, Thymus longicaulis, Anthyllis vulneraria ssp. rubriflora, Eryngium campestre, Koeleria splendens. The presence of also Convolvulus cantabrica and Satureja montana of the suborder Artemisio albae-Bromenalia erecti suggest to refer the Pian di Palma community to this syntaxon, that also fits in terms of edaphic and bioclimatic features. Classification at the association level is more difficult. Angiolini et al. (2003) referred the Bromus erectus grasslands from the calcareous massifs in southern Tuscany to two associations: i) the more xeric Cerastio etrusciBrometum erecti to Phleo-Bromion alliance; ii) Trifolio incarnati-Brometum erecti, more mesophilous and rich in species of the Molinio-Arrhenatheretea class, attributed to Bromion alliance. However, floristic and ecological differences seem too large to refer our relevés to one of these associations, especially to the more mesic one. Also due to their small number, the present relevés can only be provisionally referred to a generic Bromus erectus grouping of xerophytic type within the Artemisio albae-Bromenalia erecti. These communities are likely to represent a dynamic stage of the edaphoxerophilous series leading to the supramediterranean Quercus pubescens forest. This type of series with Bromus erectus as an intermediate stage is also reported by Scoppola \& Angiolini (1997) for other travertine garrigues between Siena and Viterbo.

\subsection{OPEN SGRUB AND SHRUBLANDS}

The shrub vegetation colonizing the rocky travertine slopes and summit area of Bagno Santo is dominated by mainly eastern Mediterranean species such as Pistacia terebinthus and Paliurus spinachristi, mixed with a few evergreen sclerophyllous species, especially Phillyrea latifolia and Rhamnus alaternus. Paliurus spina-christi is a vigorously resprouting spiny shrub favoured by sheep grazing and therefore locally dominant. Together with Cercis siliquastrum, Pistacia terebinthus and Carpinus orientalis this plant participates to distinct syntaxa of the Illyrian shrublands found in the coastal and subcoastal sectors of the Balkans, and commonly indicated as "Sibljak" (Blasi \& Di Pietro 2002). All of these species are well represented in our relevés (Table 5), with the only exception of Carpinus orientalis. Though relatively widespread in the thermophilous woodlands of Latium and most regions of central and southern Italy, this tree is still to be confirmed in the Tuscan Maremma (Selvi 2010). Other abundant tree species in our samples are Fraxinus ornus, Acer monspessulanum and Quercus pubescens, all frequent on especially carbonatic substrates of the supramediterranean hill belt of southern Tuscany. The pubescent oak plays a key role in the dynamics of this vegetation, in most cases becoming increasingly dominant and causing the progressive transformation of the Paliurus shrubland into thermophilous oak forests, especially where sheep grazing is not longer present.

Numerous species of openings and meadows occur in the herbaceous layer of this community (Bromus erectus, Allium subhirsutum, Carex caryophyllea, etc.), due to the sparse soil cover by the woody species. Well developed herbaceous communities are found in the openings of the $\mathrm{Pa}$ liurus shrubland, where ruderal and somewhat nitrophilous perennials of synanthropic vegetation such as Calamintha nepeta and Marrubium incanum are often dominant. Annual weeds of the Stellarietea class also occur in these phytocoenoses, together with some other therophytes of the travertine pavements.

In Tuscany, Paliurus spina-christi is relatively widespread in the shrublands in the warmer and drier sites of the southern parts of the region, especially in the more inland areas. However, the phytosociological affinities of the Paliurus vegetation has been scarcely studied. According to Angiolini et al. (2006), a dense shrub vegetation with Paliurus and stenomediterrannean species such as 
Phillyrea latifolia, Rosa sempervirens and Clematis flammula occurs in the Trasubbie river bed, a site of Regional Importance in the central-eastern part of the Grosseto province. However, this vegetation is only recognized as a generic grouping with no syntaxonomical position. On the other hands it differs from the Bagno Santo community in the lack of Pistacia terebinthus and Cercis siliquastrum.

In the central Tyrrhenian region (Latium), the shrublands with Paliurus spina-christi have been referred to two syntaxa of the Pruno-Rubenion suballiance: the Pistacio terebinthi-Paliuretum association from southern Latium (Blasi \& Di Pietro 2002) and the subassociation paliuretosum spinachristi of Lonicero etruscae-Rosetum sempervirentis. The latter represents dense and structured shrub formations in the hill belt of northern Latium, mainly on clayey substrates (Cutini et al. 1996, Blasi et al. 2002). Although the Pistacio terebinthiPaliuretum spinae-christi has never been recorded from Tuscany, the vegetation represented by our samples show clear floristic and ecologic affinities to this association. In particular, the frequency of the characteristic shrub species allows to refer the Bagno Santo community to this syntaxon, despite the lack of Carpinus orientalis.

\subsection{ThermophILOUS DECIDUOUS FORESTS}

The slopes of Bagno Santo are covered by a mature and relatively undisturbed broad-leaf woodland with tall trees and rich understory vegetation (Selvi \& Stefanini 2005).

Based on our relevés (Table 6) this thermophilous forest community is dominated by Quercus pubescens and Acer monspessulanum, with abundant Fraxinus ornus and, to lesser extent, the relatively more mesophilous Ostrya carpinifolia. Of particular interest is the presence of mainly eastern Mediterranean tree species that are unfrequent in Tuscany, such as Cercis siliquastrum, Celtis australis and Pistacia terebinthus. The latter occurs with aged, single-stem individuals of remarkable size, that reach the upper layers of the forest canopy. The shrub layer is rich in Paliurus spina-christi, while the herbaceous understory includes Ruscus aculeatus, Hedera helix, Tamus communis and some species linked to relatively rich and mesic forest soils, such as Melica uniflora and Brachypodium sylvaticum. A relatively good level of nutrients in the soil is indicated by slightly nitrophilous species that colonize the fissures of the rocks rich in organic forest soil, such as Parietaria officinalis and Geranium robertianum.

The syntaxonomy of the thermophilous deciduous forests in the Italian peninsula is still subject to different treatments, because of the difficult interpretation of the effects of the orographic, geopedologic and bioclimatic variations of this area and the strong impact of human activities since millennia (Blasi et al. 2004). Therefore, the Apennine deciduous forests have been classified in more or less contrasting ways by different authors (Ubaldi et al. 1987, Scoppola et al. 1995, Arrigoni 1998, Pignatti 1998, Biondi et al. 2002, 2010, Ubaldi 2003, Blasi et al. 2004, Di Pietro et al. 2010). In this study, we refer to the treatment of the order Quercetalia pubescenti-petraeae in the Italian peninsula by Blasi et al. (2004). Among the five alliances proposed in this work, that of Carpinion orientalis is the one that best matches with our relevés in terms of floristic composition. This grouping is widely distributed in the suboceanic areas of peninsular Italy (meso-mediterraneanean to upper submontane thermotypes), mainly on carbonatic soils. Four suballiances have been recognized: Laburno-Ostryenion, Lauro-Quercenion pubescentis, Cytiso sessilifolii-Quercenion pubescentis, Campanulo mediae-Ostryenion. The more thermophilous woodlands of the mid-mesomediterranean or lower hill belt are included in the LauroQuercenion pubescentis, characterized and usually dominated by Carpinus orientalis, Quercus pubescens, Acer monspessulanum, Fraxinus ornus, Pistacia terebinthus and Cercis siliquastrum. All these species are well represented in our relevés from Bagno Santo (Table 6), with the only exception of Carpinus orientalis as already observed for the shrubland communities described above. In the synoptic table of the Lauro-Quercenion pubescentis by Blasi et al. (2004), the associations floristically closer to our samples are Clematido flammulaeQuercetum pubescentis (Ubaldi et al. 1993), Roso sempervirentis-Quercetum pubescentis carpinetosum orientalis (Blasi \& Di Pietro 1998) and Lonicero etruscae-Carpinetum orientalis (Blasi et al. 2001).

Although Clematido flammulae-Quercetum pubescentis shares several species with our samples it includes a group of more mesophilous species usually found at higher elevations (Chamaecytisus hirsutus, Cytisus sessilifolius) and should therefore be excluded. Lonicero etruscae-Carpinetum orientalis is dominated by Carpinus orientalis and Ostrya carpinifolia, the former absent and the latter scarcely represented in our area; Quercus pubescens has a rela- 
tively secondary role. Furthermore one of the most important characteristic species of this association, Sesleria autumnalis, is not present in our study area.

Scoppola \& Angiolini (2001) had already reported the occurrence of woodlands close to the Roso sempervirentis-Quercetum pubescentis from the travertine outcrops in the western sector of central Italy. In particular, the floristic assemblage of the Bagno Santo forest matches that of the subassociation carpinetosum orientalis described from the Ausoni and Aurunci mountains in southern Latium (Blasi \& Di Pietro 1998). The classification problem is further complicated by the studies of Allegrezza et al. (2002) and Biondi et al. (2010). Allegrezza et al. (2002) re-analyzed the relevés of Blasi \& Di Pietro (1998) and stated that Roso sempervirentis-Quercetum pubescentis carpinetosum orientalis has to be treated as a distinct association named Pistacio terebinthi-Quercetum pubescentis; this new association was divided in two subassociations, of which the more thermophilous one was named rosetosum sempervirentis. Our relevés differ from this syntaxon by the lack of Carpinus orientalis, the presence of Celtis australis and Paliurus spina-christi, and the higher cover of Acer monspessulanum (Table 6). However, the ecological similarities and the presence of important differential species of subass. rosetosum sempervirentis such as Cercis siliquastrum and Rosa sempervirens allows to refer to the Bagno Santo forest to this syntaxon.

Finally, a taxonomical problem with potential consequences on the syntaxonomy of this forest vegetation concerns the identity of the oak species upon which Roso sempervirentis-Quercetum and Lauro-Quercenion are based. According to Biondi et al. (2010) the oak originally found in the communities of these syntaxa was not Quercus pubescens s.s. but $Q$. virgiliana $T e n$. In this case, the association and subassociation names found in the literature should be used only in a broad sense. Quercus virgiliana is a weakly differentiated species still not reported from Tuscany, even in recent floristic checklists focusing on the Tuscan Maremma (Selvi, 2010). At present there are no sufficient elements to confirm its presence in the Saturnia area, but this is possible and more detailed observations are needed to bring more light on this issue.

\section{CONCLUSION}

This study describes the vegetation types of a poorly known area of southern Tuscany, some of which of significant interest due to their ecological specificity and rarity in peninsular Italy. In particular, our data confirm the presence in Tuscany of shrub communities of the Pistacio-Paliuretum, an association previously known only from southern Latium, and allow to characterize a new therophytic association of travertine outcrops, named Sedetum hispanico-caespitosi. Besides the ecological and floristic features of the communities described, field relevés have also allowed to interpret their dynamic relationships, as schematically shown in the transect of Figure 4.

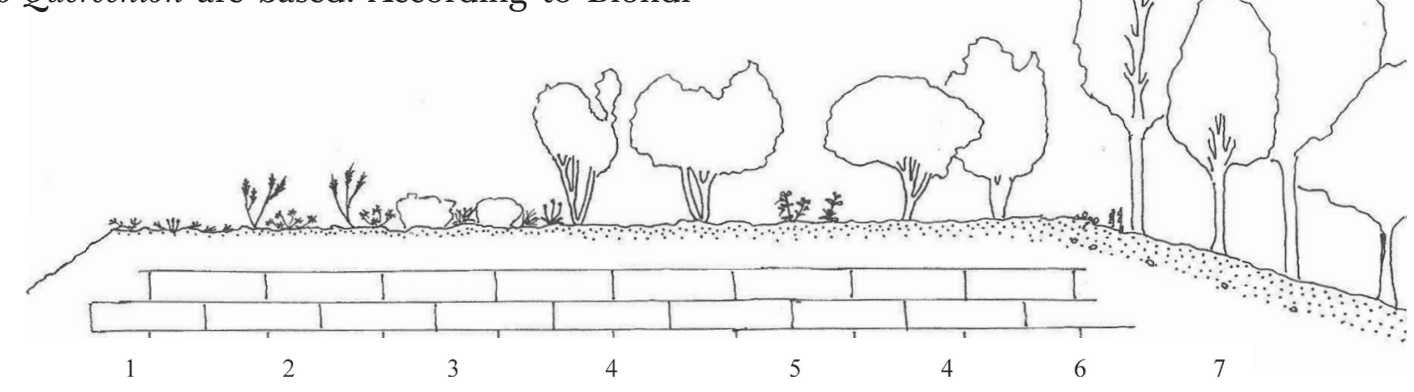

Figure 4: Schematic transects of the vegetation dynamic stages on the travertine outcrops of Poggio Bagno Santo and Pian di Palma: 1 = Sedetum hispanico-caespitosi ass. nova; 2 = Bromus erectus-dominated conenoses; 3 = Cephalario leucanthae-Saturejetum montanae euphorbietosum spinosae; 4 = Pistacio terebinthi-Paliuretum spinae-christi; 5 =Calamintha nepeta and Marrubium incanum conenoses; $6=$ Cymbalaria muralis, Muscari commutatum and Allium subhirsutum conenoses; $7=$ Pistacio terebinthi-Quercetum pubescentis rosetosum sempervirentis.

Slika 4: Shema transekta dinamike vegetacijskih tipov na travertinu na območju Poggio Bagno Santo in Pian di Palma: 1 = Sedetum hispanico-caespitosi ass. nova; 2 = združba $\mathrm{z}$ vrsto Bromus erectus; 3 = Cephalario leucanthae-Saturejetum montanae euphorbietosum spinosae; 4 = Pistacio terebinthi-Paliuretum spinae-christi; 5 = združbi z vrstama Calamintha nepeta in Marrubium incanum; 6 = združbe z vrstami Cymbalaria muralis, Muscari commutatum in Allium subhirsutum; $7=$ Pistacio terebinthi-Quercetum pubescentis rosetosum sempervirentis. 
Based on the Habitat Directive 92/43/CE, the European Interpretation Manual (European Commission, 2007) and the Italian Manual (Biondi \& Blasi 2009), our data do not support the presence of typical aspects of the priority habitat Alysso-Sedion albi (Rupicolous calcareous or basophilic grasslands, Natura 2000 code 6110), while they confirm the priority habitats FestucoBrometalia (Semi-natural dry grasslands and scrubland facies on calcareous substrates, Natura 2000 code 6210) and Thero-Brachypodietea (Pseudo-steppe with grasses and annuals, Natura 2000 code 6220).

\section{Syntaxonomic scheme}

Tuberarietea guttatae (Br.-Bl. in Br.-Bl., Roussine \& Nègre 1952) Rivas Goday \& Rivas-Martínez 1963

Brachypodietalia distachyi Rivas-Martínez 1978 Hypochoerion achyrophori Biondi \& Guerra 2008

Hypochoerenion achyrophori Biondi \& Guerra 2008 Sedetum hispanico-caespitosi ass. nova hoc loco

Parietarietea judaicae Rivas-Martínez ex Rivas Goday 1964

Cymbalaria muralis, Muscari commutatum and Allium subhirsutum coenoses

Rosmarinetea officinalis Rivas-Martínez, T.E. Diaz, F. Prieto, Loidi \& Penas 1991

Rosmarinetalia officinalis Br.-Bl. ex Molinier 1934

Artemisio albae-Saturejon montanae Allegrezza,

Biondi, Formica \& Ballelli 1997

Cephalario leucanthae-Saturejetum montanae Allegrezza, Biondi, Formica \& Ballelli 1997

euphorbietosum spinosae Allegrezza, Biondi, Formica \& Ballelli 1997

Festuco-Brometea Br.-Bl. \& Tx. ex Br.-Bl. 1949

Brometalia erecti Br.-Bl. 1936

Artemisio albae-Bromenalia erecti Biondi, Blasi ex

Biondi, Ballelli, Allegrezza, Zuccarello 1995

Bromus erectus coenoses

Rhamno-Prunetea Rivas Goday \& Borja ex Tuxen 1962

Prunetalia spinosae Tuexen 1952

Pruno-Rubion ulmifolii Bolòs 1954

Pruno-Rubenion ulmifolii Arnaiz \& Loidi 1983

Pistacio terebinthi-Paliuretum spinae-christi Blasi \&

Di Pietro 2001
Querco-Fagetea Br.-Bl. \& Vlieg. in Vlieg. 1937

Quercetalia pubescenti-petreae Klika 1933 corr. Blasi, Di Pietro \& Filesi 2004

Carpinion orientalis Horvat 1958

Lauro nobilis-Quercenion virgilianae Ubaldi 1995 corr. Biondi, Casavecchia \& Pesaresi 2010

Pistacio terebinthi- Quercetum pubescentis Allegrezza, Baldoni, Biondi, Taffetani \& Zuccarello 2002

rosetosum sempervirentis Allegrezza, Baldoni, Biondi, Taffetani \& Zuccarello 2002

\section{Other syntaxa quoted in text and tables}

Alysso-Sedion albi Oberdorfer et Müller in Müller 1961

Asplenietea trichomanis (Br.-Bl. in Meier \& $\mathrm{Br} .-\mathrm{Bl}$. 1934) Oberdorfer 1977

Campanulo mediae-Ostryenion Ubaldi 1995

Cerastio etrusci-Brometum erecti Angiolini, Riccucci \& De Dominicis 2003

Chaenorhino rubrifolii-Saxifragetum tridactylites $\mathrm{Fa}$ nelli 2007

Clematido flammulae- Quercetum pubescentis Ubaldi, Zanotti \& Puppi 1993

Crucianello latifoliae-Hypochoeridetum achyrophori Filesi, Blasi \& Di Marzio 1996

Cytiso sessilifolii-Quercenion pubescentis Ubaldi 1995

Galio-Urticetea Passarge ex Kopecký 1969

Hippocrepido siliquosae-Brachypodietum distachyi Fanelli, Bianco, De Sanctis \& Serafini Sauli 2010

Laburno-Ostryenion (Ubaldi 1995) Blasi, Di Pietro \& Filesi 2004

Lonicero etruscae-Carpinetum orientalis Blasi, Di Pietro, Filesi \& Fortini 2001

Lonicero etruscae-Rosetum sempervirentis Cutini, Fabozzi, Fortini, Armanini \& Blasi 1996 paliuretosum spina-christi Blasi, Cutini, Di Pietro \& Fortini 2002

Lygeo-Stipetea Rivas-Martínez 1978

Medicagini rigidulae-Trifolietum scabri Fanelli, Bianco, De Sanctis \& Serafini Sauli 2010Tüxen

Phleo-Bromion Biondi \& Blasi ex Biondi et al. 1995

Poetea bulbosae Rivas Goday \& Rivas-Martínez in Rivas-Martínez 1978

Quercetalia ilicis Br.-Bl. ex Molinier 1934 em. Rivas-Martínez 1975

Quercetea ilicis Br.-Bl. ex A. \& O. Bolòs 1950

Roso sempervirentis- Quercetum pubescentis Biondi 1986 carpinetosum orientalis Blasi \& Di Pietro 1998

Saxifrago-Hypochoeridetum achyrophori Biondi, Izco, Ballelli \& Formica 1997 
Sedenion caespitosi Rivas-Martínez 1978

Stellarietea mediae (Br.-Bl. 1931) Tüxen, Lohmeyer \& Preising. in Tüxen 1950

Stipo-Trachynietea Brullo 2001

Thero-Brachypodietea Br.-Bl. ex A. Bolos \& Bolos in A. Bolos 1950

Trachynion distachyae Rivas-Martínez 1978TrifolioGeranietea sanguinei $\mathrm{Th}$. Müller 1961

Trifolio scabri-Hypochoeridetum achyrophori Biondi, Izco. Ballelli \& Formica 1997

Trigonello gladiatae-Brachypodietum distachyi Fanelli, Bianco, De Sanctis, Serafini Sauli, 2010

\section{REFERENCES}

Allegrezza, M., Baldoni, M., Biondi, E., Taffetani, F. \& Zuccarello, V. 2002: Studio fitosociologico dei boschi a Quercus pubescens s.l. delle Marche e delle zone contigue dell'Appennino centro-settentionale (Italia centrale). Fitosociologia 39 (1): 161-171.

Allegrezza, M., Biondi, E., Formica, E. \& Ballelli, S. 1997: La vegetazione dei settori rupestri calcarei dell'Italia centrale. Fitosociologia 32: 91-120.

Angiolini, C., Gabellini, A., Frignani, F., Giallonardo, T. \& De Dominicis, V. 2009: Contributo alla conoscenza della vegetazione della Riserva naturale provinciale "Monte Penna" (Grosseto, Toscana meridionale) Atti Soc. tosc. Sci. nat., Mem., Ser. B, 115 (2008): 1-20.

Angiolini, C., Landi, M., Boddi, M. \& Frignani, F. 2006: La vegetazione dell'alveo fluviale del sito d'importanza regionale torrente Trasubbie (Grosseto, Toscana meridionale). Atti Soc. tosc. Sci. nat., Mem., Ser. B, 112 (2005): 127-151.

Angiolini, C., Riccucci, C. \& De Dominicis V. 2003: Brometalia erecti Br.-Bl. 1936 grasslands from Antiapennine calcareous massifs of central-southern Tuscany (Central Italy). Lazaroa 24: 61-85.

Arrigoni, P. V., 1998: La vegetazione forestale. Boschi e macchie di Toscana. Edizioni Regione Toscana.

Bigi, L \& Rustici, L. 1984: Regime idrico dei suoli e tipi climatici in Toscana. Dipartimento Agricoltura e Foreste, regione Toscana, 130 pp.

Biondi, E. 2011: Phytosociology today: methodological and conceptual evolution. Plant Biosystems 145: 19-29.

Biondi, E., Allegrezza, M. \& Zuccarello, V. 2005: Syntaxonomic revision of the Apennine grass- lands belonging to Brometalia erecti, and an analysis of their relationships with the xerophylous vegetation of Rosmarinetea officinalis (Italy). Phytocoenologia 35 (1): 129-163.

Biondi, E., Ballelli, S., Allegrezza, M. \& Zuccarello, V. 1995: La vegetazione dell'ordine Brometalia erecti Br.-Bl. 1936 nell'Appennino (Italia). Fitosociologia 30: 3-45.

Biondi, E. \& Blasi, C. (Coord.) 2009: Manuale italiano di Interpretazione degli Habitat della Direttiva 92/43/CEE. http://vnr.unipg.it/habitat/. Accessed 05/07/2012

Biondi, E., Casavecchia, S. \& Pesaresi, S. 2010: Interpretation and management of the forest habitats of the Italian peninsula. Acta Botanica Gallica 157: 687-719.

Biondi, E., Casavecchia, S., Pinzi, M., Allegrezza, M. \& Baldoni, M. 2002: The syntaxonomy of the mesophilous woods of the Central and Northern Apennines (Italy). Fitosociologia 39 (2): 71-93.

Biondi, E. \& Galdenzi, D. 2012: Phytosociological analysis of the grasslands of Montagna dei Fiori (central Italy) and syntaxonomic review of the class Festuco-Brometea in the Apennines. Plant Sociology 49(1): 91-112.

Biondi, E. \& Guerra, V. 2008: Vegetazione e paesaggio vegetale delle gravine dell'arco jonico. Fitosociologia 45 (1) suppl. 1: 57-125.

Blasi, C., Biondi, E. \& Izco, J. 2011: 100 years of plant sociology: A celebration. Plant Biosystems 145: 1-3.

Blasi, C., Cutini, M., Di Pietro, R. \& Fortini, P. 2002: Contributo alla conoscenza della suballeanza Pruno-Rubenion ulmifolii in Italia. Fitosociologia 39 (1), suppl. 2: 129-143.

Blasi, C. \& Di Pietro, R. 1998: Two new phytosociological types of Quercus pubescens s.l. woodland communities in southern Latium. Plant Biosystems 132 (3): 207-223.

Blasi, C. \& Di Pietro, R. 2002: Sulla presenza di una nuova associazione a Paliurus spina-christi L. nel Lazio meridionale. Inform. Bot. Ital. 33(2) (2001): 407-415.

Blasi, C., Di Pietro, R., Filesi, L. \& Fortini, P. 2001: Syntaxonomy, chorology and syndynamics of Carpinus orientalis communities in Central Italy. Phytocoenologia 31 (1): 33-62.

Blasi, C., Di Pietro, R. \& Filesi, L. 2004: Syntaxonomical revision of Quercetalia pubescentipetraeae in the Italian Peninsula. Fitosociologia 41(1): 87-164.

Blasi, C., Marignani, M., Copiz, R., Fipaldini, M. 
\& Del Vico, E. (Eds.) 2010: Le Aree Importanti per le Piante nelle Regioni d'Italia: il presente e il futuro della conservazione del nostro patrimonio botanico. Sapienza Università di Roma, Progetto Artiser, Roma, 224 pp.

Braun-Blanquet, J. 1932: Plant Sociology. Mac Graw Hill Book Company, New York.

Braun-Blanquet, J. 1964: Pflanzensoziologie. Springer Verlag, Wien and New York.

Braun-Blanquet, J., Roussine, N. \& Nègre, R. 1952: Les groupements végétaux de la France méditerranéenne. CNRS, Paris.

Brullo, S., Scelsi, F. \& Spampinato, G. 2001: La vegetazione dell'Aspromonte. Studio fitosociologico. Laruffa Editore, Reggio Calabria

Brullo, S. \& Guarino, R. 1999: Syntaxonomy of the Parietarietea judaicae class in Europe. Annali di Botanica 56 (1): 109-146.

Brullo, S. \& Guarino, R. 2002: La classe Parietarietea judaicae Oberd. 1977 in Italia. Fitosociologia 39(1) (suppl. 2): 5-27.

Conti, F. \& Abbate, G., Alessandrini, A. \& Blasi, C., 2005: An annotated Checklist of the Italian Vascular Flora. Min. Ambiente e Tutela Territ., Dip. Biol. Veg. Univ. "La Sapienza", Palombi Ed., Roma.

Conti, F., Alessandrini, A., Bacchetta, G., Banfi, E., Barberis, G., Bartolucci, F., Bernardo, L., Bonacquisti, S., Bouvet, D., Bovio, M., Brusa, G., Del Guacchio, E., Foggi, B., Frattini, S., Galasso, G., Gallo, L., Gangale, C., Gottschlich, G., Grünanger, P., Gubellini, L., Iiriti, G., Lucarini, D., Marchetti, D., Moraldo, B., Peruzzi, L., Poldini, L., Prosser, F., Raffaelli, M., Santangelo, A., Scassellati, E., Scortegagna, S., Selvi, F., Soldano, A., Tinti, D., Ubaldi, D., Uzunov, D. \& Vidali, M., 2007: Integrazioni alla checklist della flora vascolare italiana. Natura Vicentina 10 (2006): 5-74.

Cutini M., Fabozzi F., Fortini P., Armanini E. \& Blasi C., 1996. Coenological and phytosociological characterization of Latium. Arch. Geobot. 2 (2): 113-122.

De Foucault, B. 1999: Nouvelle contribution à une synsystématique des pelouses sèches à thérophytes. Doc. Phytosoc. 19: 47-105.

Di Pietro, R., 2011: New dry grassland associations from the Ausoni-Aurunci mountains (Central Italy) - syntaxonomical updating and discussion on the higher rank syntaxa. Hacquetia 10 (2): 183-231.

Di Pietro, R., Azzella, M. M. \& Facioni, L. 2010: The forest vegetation of the Tolfa-Ceriti moun- tains (northern Latium - central Italy). Hacquetia 9 (1): 91-150.

Di Pietro, R., Burrascano, S. \& Blasi, C., 2006: Le comunità dell'Alysso-Sedion sui Monti Prenestini (Lazio). Allionia 40: 39-49.

Di Pietro, R., Terzi, M. \& Čarni, A. 2012: Syntaxonomy and phytogeography of the FestucoBrometea dry grasslands from an alpha-Adriatic point of view. Vegetation Databases and large-scale classification, Biogeographical patterns in vegetation, Vegetation and global change, 21st Workshop of European Vegetation Survey, Vienna (Austria) 24th-27th May 2012. Book of Abstracts: 16.

European Commission 2007: Interpretation Manual of European Union Habitats, vers. EUR27. European Commission, DG Environment, Brussel.

Fanelli, G. 2007: Cryptogams-rich nanotherophytic vegetation on travertine outcrops near Tivoli. Annali di Botanica, VII: 85-92.

Fanelli, G., Bianco, P. M., De Sanctis, M. \& Serafini Sauli, A. 2010: The alliance Trachynion distachyae Rivas-Martínez 1978 in central Italy. Annali di Botanica 2010: 1-13.

Foggi, B. \& Venturi, E. 2009: Gli habitat meritevoli di conservazione della Provincia di Prato. In: Fancelli, E. (ed.), Biodiversità in Provincia di Prato. 4. Habitat. Provincia di Prato, Le Balze Editrice, Roma.

Géhu, J. M., \& Rivas-Martínez, S. 1981: Notions fondamentales de phytosociologie. Berich. int. Symp. int. Verein Vegetationsk. Syntaxonomie: 5-33.

Hammer, Ø., Harper, D. A. T. \& Ryan, P. D. 2001: PAST: Paleontological statistics software package for education and data analysis. Palaeontologia Electronica 4(1): 9pp. http://palaeo-electronica.org/2001_1/past/issue1_01. htm. PAST software available from: http:// folk.uio.no/ohammer/past.

Lastrucci, L., Foggi, B., Raffaelli, M., Benesperi, R., Gonnelli, V., Zinetti, F., Principi, G. \& Cavazzoni, D. 2009: Contributo alla conoscenza naturalistica dell'Area Naturale Protetta di Interesse Locale (ANPIL) "Serpentine di Pieve S. Stefano" (Arezzo, Toscana). Boll. Mus. reg. Sci. nat. Torino 27 (1): 101-151.

Noest, V., Van Der Maarel, E., Van Der Meulten, F. \& Van Der Loan, D. 1989: Optimum-transformation of plant species cover abundance values. Vegetatio 83: 167-178.

Oberdorfer, E. 1978: Süddeutsche Pflanzenge- 
sellschaften - Teil II. G. Fischer Verlag. Stuttgart, New York. pp. 355.

Pignatti, S. 1982: Flora d'Italia. 1-3. Edagricole, Bologna.

Pignatti, S. 1998: I boschi d'Italia. Edizioni UTET, Torino.

Pott, R. 2011: Phytosociology - A modern geobotanical method. Plant Biosystems 145: 9-18.

Press, F \& Siever, R. 1985: Introduzione alle scienze della Terra. Zanichelli, Bologna, pp. 127-150.

Regione Toscana 2010: Rete Natura 2000 - Toscana, Siti di importanza regionale. http://www. regione.toscana.it/regione/multimedia/RT/ documents/2010/08/26/cfcd9d65030cd89e0eeb371acb941093_cartografiasir2010.pdf. Accessed 05.07.2012.

Rivas-Martínez, S., Fernando-Gonzalez, F. \& Loidi, J. 1997: Syntaxonomical check-list of the Iberian Peninsula and Balearic and Canary Islands (Spain and Continental Portugal). Phytosociological Research Center (CIF), Madrid.

Rivas-Martínez, S., Díaz,T. E., Fernández-González, F., Izco, J., Loidi, J., Lousã, M. \& Penas, Á. 2002: Vascular plant communities of Spain and Portugal. Addenda to the Syntaxonomical checklist of 2001. Itinera Geobotanica 15 (1-2): 5-922.

Rivas-Martínez, S., \& Rivas-Saenz, S. 1996-2009: Worldwide Bioclimatic Classification System, Phytosociological Research Center, Spain. http://www.globalbioclimatics.org. Accessed $05 / 07 / 2012$

Scoppola, A. \& Angiolini, C. 1997: Considerazioni ecologiche e sintassonomiche su alcune garighe dell'entroterra fra Siena e Viterbo (Italia centrale). Fitosociologia 32: 121-134.

Scoppola, A. \& Angiolini, C. 2001: Therophytic vegetation of carbonate soils of central Tyrrhenian Italy: synecology and syntaxonomy. Fitosociologia 38 (1): 77-89.

Scoppola, A., Blasi, C., Abbate, G., Cutini, M., Di Marzio, P., Fabozzi, C. \& Fortini, P. 1995: Analisi critica e considerazioni fitogeografiche sugli ordini e le alleanze dei querceti e boschi misti a caducifogliedell'Italia peninsulare. Ann. Bot. LI, Suppl. 10 (1993): 81-112.

Selvi, F. \& Stefanini, P. 2005: Biotopi naturali e aree protette nella provincia di Grosseto: componenti floristiche e ambienti vegetazionali. Quaderni delle Aree Protette, Prov. Grosseto. U.O.C. Aree Protette e Biodiversità, Città di Castello, 143 pp.
Selvi, F. 2010: A critical checklist of the vascular flora of Tuscan Maremma (Grosseto province, Italy). Fl. Medit. 20: 47-139.

Servizio Geologico d'Italia 1965: Carta Geologica d'Italia, Foglio 129, S. Fiora, scala 1:100.000, Poligrafica \& Cartevalori, Napoli.

Thornthwaite, C. W. \& Mather, J. R. 1957: Instruction and tables for computing potential evapotranspiration and the water balance. Pubbl. Climatol., 10 (3): 1-311.

Tutin, T. G., et al. 1964-1980: Flora Europaea. 1-5. Cambridge University Press.

Tutin, T.G., et al. 1993: Flora Europaea. 1, $2^{\text {nd }}$ ed. Cambridge University Press.

Ubaldi, D. 2003: La vegetazione boschiva d'Italia: Manuale di Fitosociologia forestale. Clueb, Bologna, 368 pp.

Ubaldi, D., Zanotti, A. L., Puppi, G., Speranza, M. \& Corbetta, F. 1987: Sintassonomia dei boschi caducifogli mesofili dell'Italia peninsulare. Not. Fitosoc. 23: 31-62.

Ubaldi, D., Zanotti, A. L. \& Puppi, G. 1993: Les paysages forestiers de l'Emilie-Romagne et leur signification bioclimatique. Colloques phytosociologiques 21: 269-286.

Uggeri, A. 2003: Geologia dei travertini. In: AA. VV., Le Sorgenti Petrificanti: linee guida per lo studio, il monitoraggio e la gestione. Parco Regionale Campo dei Fiori. http://www.parcocurone.it/files/retenatura/travertino 2003/2 \%20UGGERI\%20geologia\%20travertini.pdf. Accessed 05/07/2012

Van der Maarel, E. 1979: Transformation of cover-abundance values in phytosociology and its effects on community similarity. Vegetatio 39 (1979): 97-114.

Venanzoni, R. \& Gigante, D. 1999: Contributo allo studio dei pascoli sommitali del Monte Tezio (Perugia, Italia). Fitosociologia 36 (1): 157-174.

Weber, H. E., Moravec, J. \& Theurillat, J. P. 2000: International Code of Phytosociological Nomenclature, $3^{\text {rd }}$. edition. J. Veg. Sc. 11: 739-768.

Westhoff, V. \& Van Der Maarel, E. 1973: The Braun-Blanquet approach. In: Whittaker R. H. (ed.), Ordination and classification of communities. Handbook of Veg. Science. Vol. 5, The Hague, Junk, pp. 617-626.

Received 29. 9. 2012

Revision received 11. 2. 2013 Accepted 14. 2. 2013 
Table 1: Annual-dominated communities of flat travertine pavements, Sedetum hispanico-caespitosi ass. nova.

Tabela 1: Združbe enoletnic na travertinskih ploščah, Sedetum hispanico-caespitosi ass. nova.

\begin{tabular}{|c|c|c|c|c|c|}
\hline Relevè nr. & 19 & $20 *$ & 14 & 15 & 18 \\
\hline Aspect & 0 & 0 & 0 & 0 & 0 \\
\hline Slope $\left(^{\circ}\right)$ & 0 & 0 & 0 & 0 & 0 \\
\hline Altitude ( $\mathrm{m}$ asl) & 235 & 235 & 250 & 257 & 245 \\
\hline Area $(\mathrm{m} 2)$ & 2 & 1,5 & 1 & 1 & 1 \\
\hline Total cover (\%) (without bryophytes) & 20 & 25 & 50 & 20 & 35 \\
\hline Site (BS: Poggio Bagno Santo; PP: Pian di Palma) & PP & PP & BS & $\mathrm{BS}$ & $\mathrm{BS}$ \\
\hline Number of species per relevè & 27 & 25 & 25 & 20 & 22 \\
\hline
\end{tabular}

Sedetum hispanico-caespitosi

Sedum caespitosum

Plantago lagopus

Saxifraga tridactylites

Sedum hispanicum

Hypochoerenion / Hypochoerion achyrophori, Brachypodietalia distachyi, Tuberarietea

Arenaria leptoclados

Catapodium rigidum

Vulpia ciliata

Cerastium brachypetalum s.1.

Minuartia hybrida

Crepis neglecta

Filago pyramidata

Hedypnois rhagadioloides

Trifolium campestre

Hypochoeris achyrophorus

Campanula erinus

Helianthemum salicifolium

Sideritis romana

Valerianella eriocarpa

Trifolium scabrum

Medicago minima

Other annual-dominated community species

(Stellarietea, Poetea bulbosae)

Anthemis arvensis

Poa bulbosa

Capsella rubella

Crepis sancta

Trifolium tomentosum

Veronica acinifolia

Cerastium ligusticum

Aphanes arvensis

Trifolium nigrescens

Erodium cicutarium

Geranium pusillum

Parentucellia latifolia

Poa annua

Ranunculus flabellatus

Sherardia arvensis 
Relevè nr.

\begin{tabular}{|c|c|c|c|c|}
\hline 19 & $20 *$ & 14 & 15 & 18 \\
\hline . & . & . & + & + \\
\hline$\cdot$ & . & 1 & . & . \\
\hline$\cdot$ & . & . & 1 & . \\
\hline$\cdot$ & . & + & . & . \\
\hline$\cdot$ & + & . &. & . \\
\hline$\cdot$ & $\cdot$ & + & $\cdot$ & $\cdot$ \\
\hline$\cdot$ & $\cdot$ & + & $\cdot$ & $\cdot$ \\
\hline+ & . & . & $\cdot$ & $\cdot$ \\
\hline$\cdot$ & + & $\cdot$ & $\cdot$ & $\cdot$ \\
\hline$\cdot$ & $\cdot$ & + & $\cdot$ & $\cdot$ \\
\hline . & . & . & $\cdot$ & $\mathrm{r}$ \\
\hline
\end{tabular}

\section{Other species}

Salvia clandestina

Eryngium campestre

Romulea bulbocodium

Calamintha nepeta

Centaurea solstitialis

Convolvulus cantabrica

Dactylis hispanica

Hordeum murinum

Juncus bufonius

Salvia verbenaca

Torilis nodosa

* = type relevé

Table 2: Chasmophytic and comophytic vegetation of steep rocks and cliff edges, Cymbalaria muralis, Muscari commutatum and Allium subhirsutum coenoses, Parietarietea.

Tabela 2: Hazmofitska in komofitska vegetacija na strmih skalah in robovih klifov, Cymbalaria muralis, Muscari commutatum and Allium subhirsutum coenoses, Parietarietea.

\begin{tabular}{lcc}
\hline Relevè nr. & $\mathbf{1 6}$ & $\mathbf{1 7}$ \\
\hline Aspect & 0 & 0 \\
Slope $\left({ }^{\circ}\right)$ & 30 & 10 \\
Altitude (m asl) & 255 & 250 \\
Area (m2) & 2 & 1 \\
Total cover (\%) & 40 & 20 \\
Site (BS: Poggio Bagno Santo; PP: Pian di Palma) & BS & BS \\
Number of species per relevè & 16 & 7 \\
\hline
\end{tabular}

Parietarietea and other chasmophytic and comophytic species

Cymbalaria muralis

Muscari commutatum

Asplenium trichomanes

Umbilicus rupestris

Polypodium cambricum

\section{Galio-Urticetea and Trifolio-Geranietea}

Allium subhirsutum

Geranium purpureum

Parietaria officinalis

Centranthus calcitrapa

$\begin{array}{ll}1 & 1 \\ + & +\end{array}$

$+\quad+$

. 1

$+\quad$.

$\begin{array}{ll}1 & 1 \\ + & + \\ \cdot & + \\ + & \end{array}$

\begin{tabular}{lcc}
\hline Relevè nr. & $\mathbf{1 6}$ & $\mathbf{1 7}$ \\
\hline Galium aparine & $\mathrm{r}$ &. \\
Arabis turrita & $\mathrm{r}$ &. \\
Other species & & \\
Aetheorrhiza bulbosa & & \\
Lens ervoides & 1 &. \\
Aristolochia lutea & + &. \\
Asparagus acutifolius & + &. \\
Ranunculus millefoliatus & + &. \\
Teucrium chamaedrys & + &. \\
\hline
\end{tabular}


Table 3: Chamaephytic garrigues, Cephalario leucanthae-Saturejetum montanae euphorbietosum spinosae, low altitude variant.

Tabela 3: Hamefitske garige, Cephalario leucanthae-Saturejetum montanae euphorbietosum spinosae, nižisnka varianta.

\begin{tabular}{lcc}
\hline Relevè nr. & $\mathbf{2 3}$ & $\mathbf{2 4}$ \\
\hline Aspect & 0 & 0 \\
Slope $\left(^{\circ}\right)$ & 0 & 0 \\
Altitude (m asl) & 235 & 235 \\
Area (m2) & 10 & 10 \\
Total cover (\%) & 80 & 70 \\
Site (BS: Poggio Bagno Santo; PP: Pian di Palma) & PP & PP \\
Number of species per relevè & 32 & 35 \\
\hline
\end{tabular}

Cephalario leucanthae-Saturejetum montanae

Satureja montana

Thymus longicaulis

Cephalaria leucantha

euphorbietosum spinosae

Euphorbia spinosa

Galium corrudifolium

other Rosmarinetea species

Teucrium capitatum

Convolvulus cantabrica

Alysso-Sedion albi

Sedum rupestre

Sedum acre

\section{Grassland species}

Bromus erectus

Allium moschatum

Iris lutescens

Urospermum dalechampii

Eryngium campestre

Filipendula vulgaris

12

$+\quad+$

. +
Relevè nr.

$23 \quad 24$

Carlina corymbosa

Potentilla hirta

Sanguisorba minor

Salvia verbenaca

Koeleria splendens

Travertine annual-dominated community species

Ranunculus flabellatus

Reichardia picroides

Sherardia arvensis

Geranium pusillum

Helianthemum salicifolium

Hypochoeris achyrophorus

Sideritis romana

23 Trifolium campestre

$+\quad+\quad$ Arenaria leptoclados

Biscutella mollis

Crepis sancta

$r \quad r$

$++$

$+\quad+$

r r

$++$

$+\quad$.

$+$

. +

$+$

$+\quad$.

r

$1 \quad 1$ Other species

Avena barbata

Dactylis hispanica

Melica transylvanica

Marrubium incanum

Romulea bulbocodium

22 Anemone hortensis

11 Coronilla scorpioides

11 Crepis neglecta

$+\quad+\quad$ Echium italicum

$+\quad+\quad$ Osyris alba

r $r \quad$ Pallenis spinosa 
Table 4: Bromus erectus grasslands, Artemisio albae-Bromenalia erecti.

Tabela 4: Travišča z vrsto Bromus erectus, Artemisio albae-Bromenalia erecti.

\begin{tabular}{lcc}
\hline Relevè nr. & $\mathbf{2 1}$ & $\mathbf{2 2}$ \\
\hline Aspect & 0 & 0 \\
Slope $\left({ }^{\circ}\right)$ & 0 & 0 \\
Altitude (m asl) & 235 & 235 \\
Area (m2) & 40 & 40 \\
Total cover (\%) & 80 & 70 \\
Site (BS: Poggio Bagno Santo; PP: Pian di Palma) & PP & PP \\
Number of species per relevè & 35 & 36 \\
\hline
\end{tabular}

Brometalia erecti and Artemisio albae-Bromenalia erecti

Bromus erectus

Eryngium campestre

Convolvulus cantabrica

Teucrium capitatum

Urospermum dalechampii

Galium corrudifolium

Koeleria splendens

Potentilla hirta

Thymus longicaulis

Tragopogon dubius

Carlina corymbosa

Filipendula vulgaris

Satureja montana

Anthyllis vulneraria ssp. rubriflora

Cleistogenes serotina

Salvia verbenaca

Sanguisorba minor

Melica transylvanica

Crupina vulgaris

Lygeo-Stipetea

Allium moschatum

Iris lutescens

43

11

11

$+\quad 1$

$+\quad 1$

$+\quad+$

$+\quad+$

$+\quad+$

$+\quad+$

$+\quad+$

$+\quad+$

r +

$1+$

+ .

$+$

. +

. +

$+\quad$.

r

\begin{tabular}{lcc}
\hline Relevè nr. & $\mathbf{2 1}$ & $\mathbf{2 2}$ \\
\hline Coronilla scorpioides & $\mathrm{r}$ & $\cdot$ \\
Pallenis spinosa & $\mathrm{r}$ & $\cdot$ \\
Bromus rubens & $\cdot$ & + \\
Poa bulbosa & $\cdot$ & + \\
Sedum hispanicum & $\cdot$ & + \\
Sideritis romana & $\cdot$ & + \\
Trifolium campestre & $\cdot$ & + \\
Trifolium stellatum & $\cdot$ & + \\
Vulpia ciliata & $\cdot$ & + \\
Crepis setosa & $\cdot$ & $\mathrm{r}$ \\
Hippocrepis ciliata & $\cdot$ & $\mathrm{r}$ \\
Other species & & \\
Euphorbia spinosa & & \\
Cephalaria leucantha & 1 & 2 \\
Romulea bulbocodium & 1 & 1 \\
Sedum rupestre & + & 1 \\
Dactylis hispanica & + & 1 \\
Orchis morio & + & + \\
Serapias vomeracea & $\mathrm{r}$ & + \\
Ornithogalum narbonense & $\mathrm{r}$ & + \\
Anemone hortensis & $\mathrm{r}$ & $\mathrm{r}$ \\
Osyris alba & + & $\cdot$ \\
Bedum acre & $\mathrm{r}$ & $\cdot$ \\
Echium italicum & $\cdot$ & + \\
Marrubium incanum & $\cdot$ & $\mathrm{r}$ \\
& $\cdot$ & $\mathrm{r}$ \\
& $\cdot$ & $\mathrm{r}$ \\
\hline
\end{tabular}

Travertine annual-dominated community species

Reichardia picroides

Helianthemum salicifolium

Tordylium apulum

Crepis neglecta

Geranium pusillum

Ranunculus flabellatus

Sherardia arvensis

Anthemis arvensis

Arenaria leptoclados

Crepis sancta

Filago pyramidata

Hypochoeris achyrophorus

Orlaya grandiflora

Veronica acinifolia

Biscutella mollis

Cerastium ligusticum 
Table 5: Open scrub and shrublands. a: Pistacio terebinthi-Paliuretum spinae-christi; $\mathbf{b}$ : transition aspect between Pistacio-Paliuretum shrublands and Quercus pubescens woods

Tabela 5: Odprta grmišča. a: Pistacio terebinthi-Paliuretum spinae-christi; b: prehod med grmišči Pistacio-Paliuretum in gozdovi Quercus pubescens woods

\begin{tabular}{|c|c|c|c|c|c|c|c|c|}
\hline & $\mathrm{a}$ & $\mathrm{a}$ & $\mathrm{a}$ & $\mathrm{a}$ & $\mathrm{a}$ & $\mathrm{a}$ & $\mathrm{a}$ & $\mathrm{b}$ \\
\hline Relevè nr. & 1 & 2 & 6 & 7 & 4 & 5 & 3 & 13 \\
\hline Aspect & 0 & $\mathrm{SE}$ & $\mathrm{W}$ & $\mathrm{SE}$ & $\mathrm{E}$ & $\mathrm{E}$ & $E$ & 0 \\
\hline Slope $\left(^{\circ}\right)$ & 0 & $<5$ & 5 & 7 & 3 & 5 & 2 & 0 \\
\hline Altitude (m asl) & 275 & 261 & 245 & 255 & 230 & 245 & 240 & 215 \\
\hline Area $(\mathrm{m} 2)$ & 100 & 100 & 50 & 100 & 60 & 70 & 70 & 200 \\
\hline Total cover (\%) (without bryophytes) & 70 & 75 & 75 & 90 & 85 & 90 & 80 & 90 \\
\hline Site (BS: Poggio Bagno Santo; PP: Pian di Palma) & $\mathrm{BS}$ & $\mathrm{BS}$ & BS & $\mathrm{BS}$ & $\mathrm{BS}$ & $\mathrm{BS}$ & BS & PP \\
\hline Number of species per relevè & 38 & 44 & 23 & 27 & 49 & 50 & 33 & 39 \\
\hline
\end{tabular}

Pistacio terebinthi-Paliuretum spinae-christi

Paliurus spina - christi

Pistacia terebinthus

Phyllirea latifolia

Cercis siliquastrum

Melica transylvanica

Pruno-Rubenion, Pruno-Rubion ulmifolii, Prunetalia spinosae, Rhamno-Prunetea

Asparagus acutifolius

Ruscus aculeatus

Clematis flammula

Pyrus amygdaliformis

Rubia peregrina

Rosa sempervirens

Crataegus monogyna

Prunus spinosa

Tamus communis

Quercetalia pubescenti-petraeae, Querco-Fagetea

Fraxinus ornus

Acer monspessulanum

Quercus pubescens

Ulmus minor

Celtis australis

\section{Quercetalia, Quercetea ilicis}

Rhamnus alaternus

Cyclamen repandum

Olea sylvestris

Osyris alba

Carex distachya

Smilax aspera

\section{Other species}

Bromus erectus

Allium subhirsutum

Calamintha nepeta

Carex caryophyllea

Dactylis hispanica

Convolvulus cantabrica 
Relevè nr.

Arabis hirsuta

Orlaya grandiflora

Urospermum dalechampii

Brachypodium distachyum

Bromus sterilis

Cynosurus echinatus

Knautia integrifolia

Teucrium chamaedrys

Hypochoeris achyrophorus

Serratula cichoracea

Sideritis romana

Thymus longicaulis

Aristolochia rotunda

Eryngium campestre

Euphorbia spinosa

Brachypodium ramosum

Gastridium ventricosum

Geranium robertianum

Crepis zacintha

Geranium purpureum

Teucrium capitatum

Trifolium angustifolium

Trifolium stellatum

Aegilops geniculata

Aristolochia lutea

Gaudinia fragilis

Ranunculus millefoliatus

Trifolium lappaceum

Aetheorrhiza bulbosa

Anemone hortensis

Anthemis arvensis

Arenaria leptoclados

Arum italicum

Bromus hordeaceus

Bromus rubens

Campanula rapunculus

Carlina corymbosa

Catapodium rigidum

Crepis neglecta

Euphorbia exigua

Galium corrudifolium

Geranium dissectum

Lathyrus cicera

Orchis tridentata

Poa bulbosa

Poa trivialis

Salvia clandestina

Sanguisorba minor

Sedum rupestre

Torilis japonica

Torilis nodosa

Trifolium campestre

\begin{tabular}{|c|c|c|c|c|c|c|c|}
\hline 1 & 2 & 6 & 7 & 4 & 5 & 3 & 13 \\
\hline+ & + & $\mathrm{r}$ & . & . & $\mathrm{r}$ & . & $\mathrm{r}$ \\
\hline . & $\mathrm{r}$ & . & . & $\mathrm{r}$ & + & + & $\mathrm{r}$ \\
\hline+ & . & . & $\mathrm{r}$ & $\mathrm{r}$ & . & + & + \\
\hline . & $\mathrm{r}$ & + & . & 1 & 1 & . & . \\
\hline 1 & 1 & + & . & . & . & . & + \\
\hline . & . & + & + & 1 & 1 & . & . \\
\hline . & . & $\mathrm{r}$ & + & + & 1 & . & . \\
\hline . & 1 & . & $\mathrm{r}$ & . & + & . & + \\
\hline . & . & . & + & + & + & $\mathrm{r}$ & . \\
\hline . & $\mathrm{r}$ & . & + & . & $\mathrm{r}$ & $\mathrm{r}$ & . \\
\hline . & . & . & $\mathrm{r}$ & $\mathrm{r}$ & . & + & + \\
\hline . & . & . & . & + & + & + & + \\
\hline . & . & 1 & 1 & . & + & . & . \\
\hline . & . & . & . & + & . & 1 & 1 \\
\hline 1 & 1 & . & . & . & . & . & + \\
\hline . & + & . & . & . & + & . & 1 \\
\hline . & . & . & . & 1 & + & + & . \\
\hline . & . & 1 & + & . & $\mathrm{r}$ & . & . \\
\hline . & . & . & . & + & $\mathrm{r}$ & . & $\mathrm{r}$ \\
\hline+ & + & . & . & . & . & . & + \\
\hline . & . & . & . & $\mathrm{r}$ & . & + & + \\
\hline . & + & . & . & + & $\mathrm{r}$ & . & . \\
\hline+ & . & . & . & . & $\mathrm{r}$ & . & + \\
\hline . & . & . & . & 1 & 1 & . & . \\
\hline+ & 2 & . & . & . & . & . & . \\
\hline . & . & . & . & 1 & + & . & . \\
\hline+ & 1 & . & . & . & . & . & . \\
\hline . & . & . & $\mathrm{r}$ & 1 & . & . & . \\
\hline+ & + & . & . & . & . & . & . \\
\hline+ & + & . & . & . & . & . & . \\
\hline+ & . & . & . & + & . & . & . \\
\hline . & + & . & . & . & . & . & + \\
\hline $\mathrm{r}$ & + & . & . & . & . & . & . \\
\hline . & . & $\cdot$ & $\cdot$ & + & + & . & . \\
\hline . & . & . & . & + & + & . & . \\
\hline . & $\cdot$ & . & + & . & $\mathrm{r}$ & . & . \\
\hline . & . & . & . & $\mathrm{r}$ & . & . & + \\
\hline . & + & . & $\mathrm{r}$ & . & . & . & $\cdot$ \\
\hline . & . & . & . & + & . & . & + \\
\hline . & . & . & . & . & $\mathrm{r}$ & . & + \\
\hline . & . & . & . & . & . & + & + \\
\hline . & . & . & . & $\mathrm{r}$ & + & . & . \\
\hline $\mathrm{r}$ & + & . & . & . & . & . & . \\
\hline+ & $\mathrm{r}$ & . & . & . & . & . & . \\
\hline+ & . & . & . & . & . & . & + \\
\hline+ & + & . & . & . & . & . & . \\
\hline . & . & . & . & + & + & . & . \\
\hline . & . & . & . & $\mathrm{r}$ & . & + & . \\
\hline+ & + & . & . & . & . & . & . \\
\hline . & + & $\mathrm{r}$ & . & . & . & . & . \\
\hline . & . & . & . & + & + & . & . \\
\hline . & . & . & . & + & + & . & . \\
\hline
\end{tabular}


Relevè nr.

Trifolium scabrum

Vicia sativa ssp. nigra

Ammoides pusilla

Brachypodium rupestre

Cerastium ligusticum

Reichardia picroides

Satureja montana

Asplenium ceterach

Avena barbata

Biscutella mollis

Bombycilaena erecta

Briza maxima

Bupleurum baldense

Campanula erinus

Carex divulsa

Centaurea bracteata

Centaurium erythraea

Coronilla scorpioides

Crepis sancta

Cynoglossum creticum

Dorycnium hirsutum

Filipendula vulgaris

Fumaria capreolata

Galium aparine

Geranium lucidum

Iris lutescens

Lathyrus ochrus

Linum strictum

Lolium perenne

Marrubium incanum

Medicago arabica

Medicago minima

Melilotus neapolitana

Nigella damascena

Ophrys sphecodes

Pallenis spinosa

Plantago bellardi

Plantago lagopus

Poa pratensis

Potentilla hirta

Ruscus hypoglossum

Tanacetum corymbosum ssp. achilleae

Theligonium cynocrambe

Tordylium apulum

Tragopogon dubius

Trifolium cherleri

Trifolium striatum

Urospermum picroides

Veronica acinifolia

Vulpia bromoides

\begin{tabular}{|c|c|c|c|c|c|c|c|}
\hline 1 & 2 & 6 & 7 & 4 & 5 & 3 & 13 \\
\hline$\cdot$ & . & . & . & + & . & . & + \\
\hline . & + & . & . & . & $\mathrm{r}$ & . & . \\
\hline . & . & . & . & 1 & . & . & . \\
\hline . & . & . & . & . & . & 1 & . \\
\hline . & . & . & . & . & . & . & 1 \\
\hline . & . & . & . & . & . & . & 1 \\
\hline . & . & . & . & . & . & . & 1 \\
\hline . & $\mathrm{r}$ & . & . & . & . & . & . \\
\hline . & . & . & . & + & . & . & . \\
\hline . & . & . & . & . & . & . & + \\
\hline . & . & . & . & + & . & . & . \\
\hline . & . & . & . & + & . & . & . \\
\hline . & . & . & . & . & + & . & . \\
\hline . & . & . & $\mathrm{r}$ & . & . & . & . \\
\hline+ & . & . & . & . & . & . & . \\
\hline . & . & . & . & . & . & + & . \\
\hline . & . & . & . & $\mathrm{r}$ & . & . & . \\
\hline . & . & . & . & . & . & . & $\mathrm{r}$ \\
\hline . & . & . & . & . & . & . & + \\
\hline$\cdot$ & . & $\cdot$ & . & . & . & $\cdot$ & $\mathrm{r}$ \\
\hline . & . & . & . & . & . & + & . \\
\hline . & . & . & . & . & . & $\mathrm{r}$ & . \\
\hline . & $\mathrm{r}$ & . & . & . & . & . & . \\
\hline . & + & . & . & . & . & . & . \\
\hline . & . & $\mathrm{r}$ & . & . & . & . & 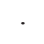 \\
\hline . & . & . & . & . & . & . & $\mathrm{r}$ \\
\hline $\mathrm{r}$ & . & . & . & . & . & . & . \\
\hline . & . & . & . & $\mathrm{r}$ & . & . & . \\
\hline . & $\cdot$ & . & . & . & + & . & . \\
\hline . & . & . & . & . & . & . & $\mathrm{r}$ \\
\hline . & + & . & . & . & . & . & . \\
\hline+ & . & . & . & . & . & . & . \\
\hline . & . & . & . & . & . & $\mathrm{r}$ & $\cdot$ \\
\hline . & . & . & . & + & . & . & $\cdot$ \\
\hline$\cdot$ & $\cdot$ & . & . & . & $\mathrm{r}$ & . & 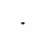 \\
\hline . & . & . & . & $\mathrm{r}$ & . & . & . \\
\hline . & . & . & . & + & . & . & . \\
\hline . & . & . & . & + & . & . & 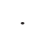 \\
\hline . & . & . & . & . & + & . & . \\
\hline . & . & . & . & . & . & + & . \\
\hline . & . & . & $\mathrm{r}$ & . & . & . & . \\
\hline . & . & . & . & . & $\mathrm{r}$ & . & . \\
\hline . & $\mathrm{r}$ & . & . & . & . & . & . \\
\hline+ & . & . & . & . & . & . & . \\
\hline$\cdot$ & . & . & . & . & . & + & . \\
\hline . & . & . & . & + & . & . & . \\
\hline . & $\cdot$ & $\cdot$ & $\cdot$ & $\cdot$ & + & . & . \\
\hline . & . & $\mathrm{r}$ & . & . & . & . & . \\
\hline+ & . & . & . & . & . & . & . \\
\hline+ & . & . & . & . & . & . & . \\
\hline
\end{tabular}


Table 6: Thermophilous deciduous forests dominated by Quercus pubescens and Acer monspessulanum, Pistacio terebinthi-Quercetum pubescentis rosetosum sempervirentis.

Tabela 6: Termofilni listopadni gozdovi z prevladujočimi vrstami Quercus pubescens in Acer monspessulanum, Pistacio terebinthi-Quercetum pubescentis rosetosum sempervirentis.

\begin{tabular}{lccccc}
\hline Relevè nr. & $\mathbf{8}$ & $\mathbf{9}$ & $\mathbf{1 0}$ & $\mathbf{1 2}$ & $\mathbf{1 1}$ \\
\hline Aspect & 0 & $\mathrm{E}$ & 0 & $\mathrm{~W}$ & $\mathrm{~W}$ \\
Slope $\left({ }^{\circ}\right)$ & 0 & 8 & 0 & 20 & 15 \\
Altitude (m asl) & 220 & 240 & 240 & 210 & 255 \\
Area (m2) & 200 & 250 & 200 & 300 & 250 \\
Total cover (\%) (without bryophytes) & 95 & 95 & 95 & 95 & 95 \\
Site (BS: Poggio Bagno Santo; PP: Pian di Palma) & PP & BS & BS & PP & BS \\
Number of species per relevè & 28 & 46 & 34 & 31 & 29 \\
\hline
\end{tabular}

\section{Pistacio terebinthi-Quercetum pubescentis}

Smilax aspera

Acer campestre

Pistacia terebinthus

\section{rosetosum sempervirentis}

Cercis siliquastrum

Rosa sempervirens

Brachypodium ramosum

Cyclamen repandum

local variant differential species

Paliurus spina - christi

Celtis australis

$\begin{array}{lllll}. & 2 & . & + & 2 \\ . & 1 & 1 & . & . \\ . & + & . & . & .\end{array}$

\section{Lauro-Quercenion, Carpinion orientalis}

Acer monspessulanum

Asparagus acutifolius

Clematis flammula

Rubia peregrina

Phyllirea latifolia

Ostrya carpinifolia

Lonicera etrusca

Anemone hortensis

Arabis turrita

\section{Quercetalia pubescenti-petraeae, Querco-Fagetea}

Quercus pubescens

Fraxinus ornus

Ruscus aculeatus

Hedera helix

Tamus communis

Cornus mas

Melica uniflora

Brachypodium sylvaticum

Melittis melissophyllum

Viola alba ssp. dehnhardtii

Lithospermum purpurocaeruleum

Helleborus foetidus

Poa sylvicola

Silene italica 
Relevè nr.

Quercus cerris

Stachys officinalis

Scutellaria columnae

Pulicaria odora

Lathyrus venetus

Cyclamen hederifolium

Geum urbanum

Other species

Geranium robertianum

Allium subhirsutum

Aristolochia rotunda

Brachypodium rupestre

Crataegus monogyna

Myrrhoides nodosa

Parietaria officinalis

Calamintha nepeta

Quercus ilex

Serratula cichoracea

Arabis hirsuta

Asplenium onopteris

Cardamine graeca

Carex distachya

Geranium lucidum

Ranunculus velutinus

Torilis japonica

Bromus erectus

Carex hallerana

Filipendula vulgaris

Stellaria media

Alliaria petiolata

Asplenium trichomanes

Bellis perennis

Bromus sterilis

Carex depauperata

Carlina corymbosa

Cruciata glabra

Cymbalaria muralis

Cynosurus echinatus

Ficus carica

Helianthemum nummularium

Lotus hispidus

Melica transylvanica

Moehringia pentandra

Ornithogalum etruscum

Prunus spinosa

Ranunculus bulbosus

Rhamnus alaternus

Sonchus oleraceus

Theligonium cynocrambe

Thymus longicaulis

Trifolium ochroleucum

Umbilicus rupestris
8

9

10

12

11

1

.

$+$

$+$



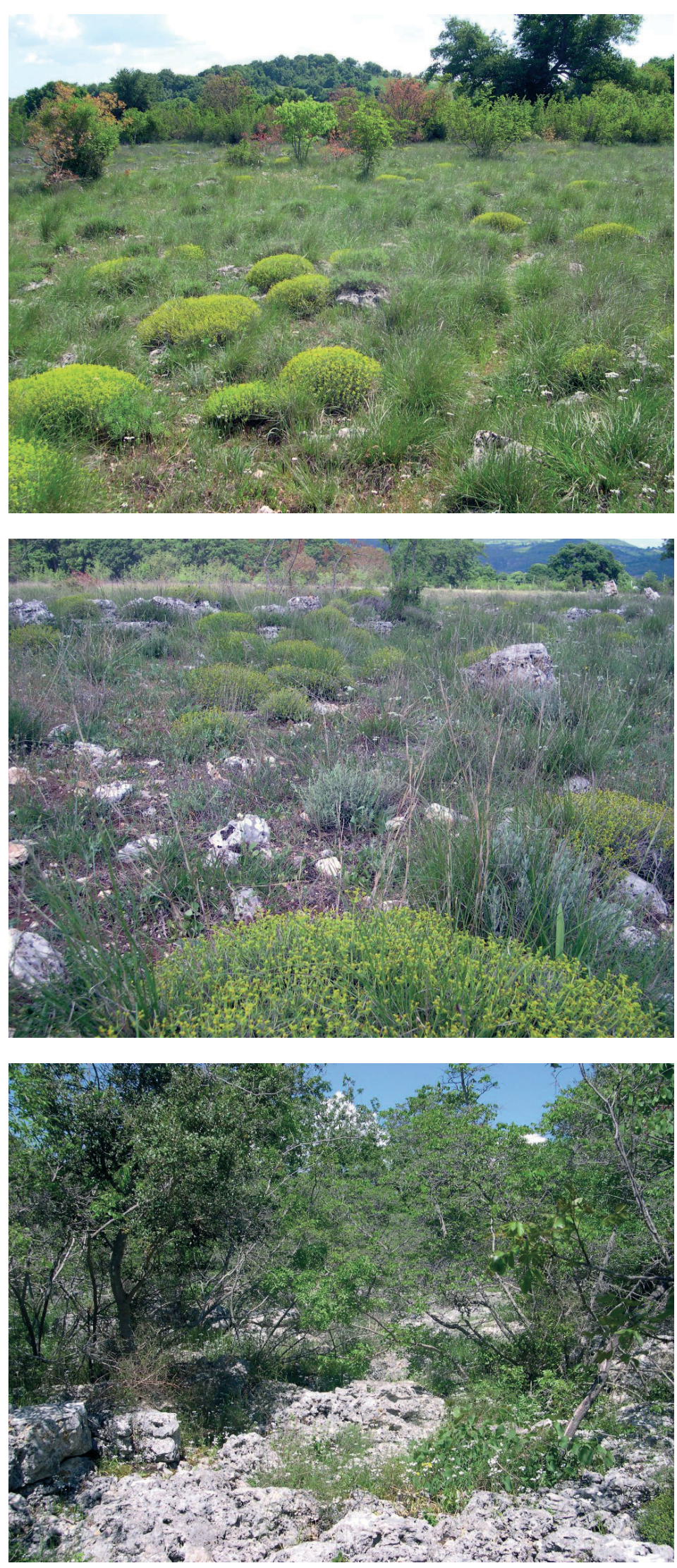

Pian di Palma Bromus erectus grasslands, with cushions of Euphorbia spinosa.

Travišča $\mathrm{z}$ vrsto Bromus erectus in blazinicami Euphorbia spinosa na območju Pian di Palma.
Pian di Palma chamaephytic garrigues with $E \mathcal{~}$ phorbia spinosa, Satureja montana, Helichrysum italicum and others.

Hamefitska gariga z vrstami Euphorbia spinosa, Satureja montana, Helichrysum italicum in drugimi na območju Pian di Palma.
Shrub community of Pistacio terebinthi-Paliuretum spinae-christi on the rocky hill slopes of Poggio Bagno Santo.

Grmiščne združbe Pistacio terebinthi-Paliuretum spinae-christi na gričevju Poggio Bagno Santo. 

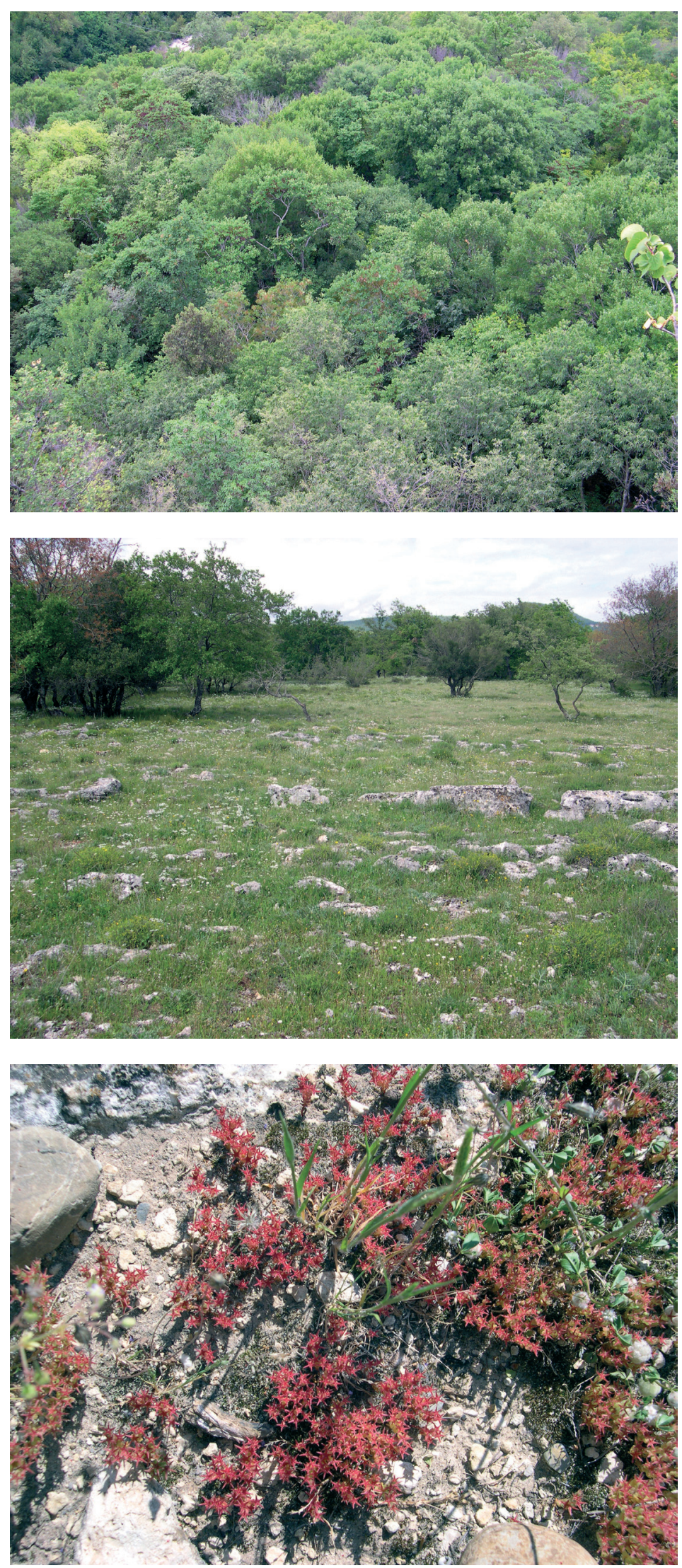

Aerial view of the mixed thermophilous deciduous forest (Pistacio terebinthi-Quercetum pubescentis rosetosum sempervirentis) on the slopes of Poggio Bagno Santo facing the Albegna river.

Pogled iz zraka na mešane termofilne listopadne gozdove (Pistacio terebinthi-Quercetum pubescentis rosetosum sempervirentis) na pobočju gričevja Poggio Bagno Santo proti reki Albegna.

The flat travertine pavement of Pian di Palma, with open woodland and species-rich grassland communities.

Ravne plošče travertina na območju Pian di Palma z odprtimi gozdovi in vrstno bogatimi travišči.

Sedum caespitosum, one of the most physiognomically typical species of the annual-dominated communities on flat travertine pavements (Sedetum hispanico-caespitosi).

Sedum caespitosum je vrsta, ki daje značilen fiziognomski videz združbam na travnatih ploščah, v katerih prevladujejo anoletnice (Sedetum hispanico-caespitosi). 